Katrin Wesche is an assistant professor of economics at the Institut für Internationale Wirtschaftspolitik, Universität Bonn in Bonn, Germany Cindy Gleit provided research assistance. The author is grateful to Dan Thornton for his invaluable help, and to Barry Jones and Travis Nesmith, whose comments substantially improved this paper.

\section{The Demand for Divisia Money in a Core Monetary Union}

\section{Katrin Wesche}

then he ratification of the Maastricht Treaty and the agreement on the constitution of the European Central Bank have given rise to a number of papers investigating the demand for money in Europe. In most of this work, conventional simplesum aggregates have been used to measure the quantity of money in the European Union. ${ }^{1}$ However, proponents of the aggregation theoretic approach to the demand for money argue that simple-sum measures lack adequate theoretical foundations and fail to capture the theoretical notion of money. This is especially true for broad monetary aggregates, which include components that are imperfect substitutes for transactions media. The use of simple-sum aggregates in the investigation of European money demand, therefore, is questionable - especially since the European Central Bank will presumably target a broad monetary aggregate.

Some research on European money demand has considered aggregation theory. For example, Fase and Winder (1994) and Fase (1996) compute European Divisia monetary indexes ${ }^{2}$ for different groups of countries in the European Union and find that European money demand is fairly stable. A similar result is obtained by Monticelli and Papi (1996), who construct a currency-equivalent index proposed by Rotemberg, Driscoll, and Poterba (1995).

Both studies construct indexes by using the direct and the indirect methods. In the indirect method, an index is constructed for each country, and the European aggregate is taken to be the average of the national indexes. In the direct method, the components are added across countries, and weighted averages of national interest rates are used to obtain the user cost for each component. Neither approach is strictly consistent with aggregation theory, because aggregation by averaging national Divisia implicitly assumes perfect substitutability across indexes, and the summation of monetary assets across countries requires that assets, denominated in different currencies, be perfect substitutes.

Aggregation over different national moneys should employ appropriate methods. ${ }^{3}$ European monetary aggregation that uses indexes for monetary services is particularly attractive because such indexes can account for the different paces of financial innovation in the countries of Europe. The main contribution of this paper is to apply the aggregation theoretic framework consistently to money holdings of European residents. ${ }^{4}$ The first section presents the definition of the Divisia index. The second derives a European Divisia index. In the third, the Divisia index and a simple-sum measure of European money are compared and analyzed.

\section{THE DIVISIA MONETARY INDEX}

Most writers define money according to the functions it performs. ${ }^{5}$ Monetary assets serve as a medium of transaction, a store of value, and a unit of account, with the medium-of-transaction function being crucial for distinguishing monetary assets from other financial assets. It has, however, become commonplace for monetary aggregates to include financial assets that are not mutually exchangeable. ${ }^{6}$ For example, savings and time deposits are included in the M2 monetary aggregate, despite the fact that they cannot be used to make transactions.
${ }^{1}$ See, e.g., Kremers and Lane (1990), Monticelli and StraussKahn (1991), Artis et al. (1993).

2 The term Divisia index is used throughout the paper to refer to the Törnqvist-Theil discrete time approximation to the continuous time index suggested by Divisia (1926).

${ }^{3}$ Marquez (1987) tackles this problem by applying the aggregation approach to money demand in an open economy. But since his focus is on the holdings decisions of residents, only residents' holdings of foreign currency are included. The same is the case in the study by Ewis and Fisher (1984), who find strong substitutability between domestic and foreign monetary assets with a translog utility model.

${ }^{4}$ This paper focuses on the consumer's problem. For models applicable to firms and financial intermediaries, see Bamett (1987).

${ }^{5}$ See Osborne (1992) for a more detailed survey on different approaches to the definition of money.

${ }^{6}$ In accordance with aggregation theory, a monetary aggregate is defined over a weakly separable block in the utility function. This definition is rarely implemented because tests for blockwise weak separability are biased towards rejection; a single rejection in the data renders the formation of a separable group impossible. For a discussion of separability tests and applications to U.S. monetary data, see Swofford and Whitney (1986, 1987, 1988, 1994). 
${ }^{7}$ Barry Jones and Travis Nesmith point out that the aggregation approach provides a "negative" definition of monetary services by specifying that the store-ofvalue function is not a monetary service. Nevertheless, as the Divisia index intends to measure a monetary senvices flow (and given the difficulties with testing for weak separability), some a priori idea of which assets contain a monetary services component is useful for determining which assets to include in a monetary aggregate (see Bamett, 1982, p. 697).

${ }^{8}$ Aggregation of real monetary assets is equivalent to aggregating nominal assets and deflating the monetary services index afterwards (see Anderson, Jones, and Nesmith, 1997b).

${ }^{9}$ Actually, the single-period utility function is a special case. The solution to the single-period utility function is equivalent to an intertemporal optimization if current-period monetary assets are weakly separable from the other decision variables in the consumer's utility function.

${ }^{10}$ Money is included in the utility function, since it provides services such as convenience, liquidity, and information. For the equivalence of putting money into the utility function or solely into the budget constraint, see Barnett, Fisher, and Serletis (1992, p. 2093). Barnett (1987) shows that with money entering the production function as durable physical capital, the user cost formula also applies for firms. The user costs also have the same form for financial intermediaries, if no reserve requirements are present.
The idea in the aggregation approach is to extract the store-of-value function from all financial assets, so that what remains are the "monetary services" for the assets. ${ }^{7}$ It is assumed that the store-ofvalue characteristic of an asset is reflected by its investment yield and that one asset, called the benchmark asset, provides only the store-of-value function and no other. In addition, instead of simply adding such assets together, as it is done in simple-sum aggregation, the theoretical approach of aggregation creates an index of monetary services that has microeconomic foundations. While conventional monetary aggregates are derived in a simple accounting procedure from the banking sector's balance sheet, the theoretical approach, or Divisia index, is based on the optimizing behavior of economic agents. One way to see how this aggregation theory approach compares with simple-sum aggregation is to assume that individuals maximize a utility function composed of a number of real monetary assets, $M_{i} / p^{*}, 8$ and commodities that are directly consumed, $\mathrm{C}_{\mathrm{j} .}{ }^{9}$ That is, consumers maximize

$U=U\left(\frac{M_{1}}{p^{*}}, \frac{M_{2}}{p^{*}}, \ldots, \frac{M_{1}}{p^{*}}, C_{1}, C_{2}, \ldots, C_{\jmath}\right)$,

subject to a budget constraint, where ${ }^{*}$ is a true cost-of-living index. ${ }^{10}$ The I monetary assets commonly include assets that are used directly in transactions-i.e., cash and checkable deposits-but may include other financial assets such as saving and time deposits as well.

The aggregation approach assumes that there exists an aggregator function,

$$
\mathrm{M}=f\left(\frac{\mathrm{M}_{1}}{\mathrm{p}^{*}}, \frac{\mathrm{M}_{2}}{\mathrm{p}^{*}}, \ldots, \frac{\mathrm{M}_{1}}{\mathrm{p}^{*}}\right)^{11}
$$

The utility function can be rewritten as

$$
U=F\left(M, C_{1}, C_{2}, \ldots, C_{j}\right),
$$

so that the demand for money can be separated from the demand for consumption goods. Consumers can be seen as allocating their budget in two stages (Green, 1964). In the first stage, the consumer chooses the optimal quantities of consumption goods and optimal total expenditures on monetary assets. In the second stage, the monetary expenditures are allocated among specific monetary assets. The solution to the maximization problem that uses the two-step approach is identical to the one that uses a one-step approach so long as the marginal rate of substitution between any two monetary assets does not depend on the quantities of commodities consumed (Barnett, Fisher, and Serletis, 1992). This condition, referred to as blockwise weak separability, is necessary for economic aggregation. ${ }^{12}$ If this condition is satisfied, the monetary aggregate behaves like a single economic good for which a demand function exits. ${ }^{13}$ Under these assumptions, $M$ is the monetary aggregate that we desire to measure.

The discrete-time approximation to the continuous-time Divisia index is exact for a function that can provide a second-order approximation to any arbitrary aggregator function, $M$, and therefore belongs to the class of superlative indexes, as defined by Diewert (1976). ${ }^{14}$ The growth rate of the Divisia index is defined as

$$
\begin{aligned}
& \log Q_{t}-\log Q_{t-1} \\
= & \sum_{i=1}^{N} \bar{s}_{i t}\left(\log \frac{M_{i t}}{p_{t}^{*}}-\log \frac{M_{i, t-1}}{p_{t-1}^{*}}\right), \\
\bar{s}_{i t} & =\frac{1}{2}\left(s_{i t}+s_{i, t-1}\right) .
\end{aligned}
$$

with the expenditure shares

$$
\mathrm{S}_{\mathrm{it}}=\frac{\pi_{\mathrm{it}} \mathrm{M}_{\mathrm{it}}}{\sum_{\mathrm{k}=1}^{\mathrm{K}} \pi_{\mathrm{kt}} \mathrm{M}_{\mathrm{kt}}} .
$$

In the aggregation approach, money is regarded as a durable good that yields services in facilitating transactions and providing liquidity. The user cost, $\pi_{i t}$, for monetary services therefore can be derived in a fashion analogous to that used to derive the user cost for a durable consumption good (see Donovan, 1978; Barnett, 1978, 1987)..$^{15}$ For a durable consumption good, the one-period holding cost, or rental price, 
is given by the cost of the purchase of the good in the current period less the discounted expected resale value of the depreciated good in the next period. ${ }^{16}$ The opportunity cost of a component monetary asset is measured by the user cost, $\pi_{i t}$, of the ith monetary asset, defined by

$$
\pi_{i t}=p_{t}^{*} \frac{R_{t}-r_{i t}}{1+R_{t}},
$$

which is a function of the difference between the own rate of return on the ith asset, $r_{i}$, and the return on a so-called benchmark asset, $R$. The benchmark asset is assumed to provide no monetary services and is used only to transfer wealth between periods. The user cost is larger, the smaller is the own rate of return. The own rate of return on cash is taken to be zero and therefore cash has the highest user cost. On the other hand, a monetary asset earning the benchmark's rate of return would not contribute to the growth of the index in that period. ${ }^{17}$

The aggregation approach does not consider aggregation over a diverse population of individuals. To deal with the problem, it uses the concept of a representative consumer. In essence, the behavior of the representative consumer is assumed to reflect the average behavior of the population. Researchers frequently employ the representative agent methodology to avoid the problems that can arise from aggregation over a diverse group of individuals (see Phlips, 1974, p. 100). The assumption of a representative consumer is very restrictive, but it is assumed in simple-sum aggregation as well.

\section{EUROPEAN MONETARY AG GREGATION}

To derive a European monetary aggregate, researchers assume that consumers hold a diversified portfolio of European currencies with different degrees of liquidity. ${ }^{18} \mathrm{~N}$ evertheless, in contrast to the computation of a Divisia index for a single country, an additional difficulty arises when the Divisia index is applied to financial assets across countries. Namely, the value of component assets changes as exchange rates vary. Hence, the aggregation approach must be modified to account for expected changes in the exchange rate.

The stock of monetary assets is redefined to account for currencies of different denominations. That is, the representative consumer is assumed to hold real monetary assets, denominated in different European currencies,

$$
\frac{M_{i k, t} / e_{k, t}}{p_{t}^{*}},
$$

where $M_{i k}$ is the ith monetary asset denominated in the kth country's currency and $e_{k}$ is the kth country's exchange rate relative to a weighted currency basket like the ECU (see Wesche, 1996 for details). As it is assumed that the representative consumer al locates his consumption expenditure on European consumption goods, the true cost-of-living price index, $p^{*}$, is defined in terms of this bundle of European consumption goods.

In addition, the own rate of return, $r_{i k}$, of a component monetary asset has to take account of the expected depreciation or appreciation of the respective currency relative to the weighted exchange rate. The nominal user cost for the European Divisia index thus becomes

$$
\pi_{\mathrm{ik}, \mathrm{t}}=\mathrm{p}_{\mathrm{t}}^{*} \frac{\mathrm{R}_{\mathrm{t}}-\mathrm{r}_{\mathrm{ik}, \mathrm{t}}+\delta_{\mathrm{k}, \mathrm{t}}^{\mathrm{e}}}{1+\mathrm{R}_{\mathrm{t}}},
$$$$
\text { with } \quad \delta_{k, t}^{e}=\frac{e_{k, t+1}^{e}-e_{k, t}}{e_{k, t+1}}
$$

being the expected depreciation of the $k^{\text {th }}$ country's currency and $R_{t}=\max \left(R_{k, t}-\delta_{k, t}^{e}\right)$ the European benchmark yield, which is the highest yield on a portfolio of European bonds, corrected for expected depreciation of the exchange rate. The main difference between the user cost in the multiplecountry framework and the single-country case is that the user cost reflects the expected capital gain (or loss) on money
${ }^{11}$ Technically, $M$ is the function evaluated at its optimal point.

${ }^{12}$ The precise conditions under which aggregation is valid are stated in Anderson, Jones, and Nesmith (1997a).

${ }^{13}$ The condition of blockwise weak separability can be tested by examining the consistency of consumer choices. A violation of consistency would occur if consumers chose a different market basket even if prices remained unchanged.

${ }^{14}$ In fact, the continuous time Divisia index is always exact. In contrast, the simple-sum is the exact index if, and only if, all of the component assets are perfect substitutes. Moreover, the simple-sum has no statistical properties in any case.

${ }^{15}$ The user-cost formula is derived from a dynamic budget constraint. User costs are correct even if aggregation is not valid.

${ }^{16}$ Even if the good is held more than one period, it can be assumed that the holder sells the good to himself at the end of each period (see Donovan, 1978).

${ }^{17}$ This implies that the asset does not provide any marginal utility in that period (Barnett, 1996).

${ }^{18}$ This says nothing about the substitutability of different national moneys. Indeed, failure of the representative consumer to react in his portfolio composition to exchange-rate changes indicates that different currencies are not close substitutes. 
${ }^{19}$ Unless otherwise indicated, all data are from the International Monetary Fund's International Financial Statistics.

20 The weighted exchange rate uses GDP weights, converted with purchasing power parities from the OECD (1990).

${ }^{21}$ Here I construct the Divisia index in a single stage. One could also (with the appropriate separability assumptions) use a two-stage aggregation approach in which the consumer first allocates his expenditures among monetary assets in different national currencies, and then among monetary assets denominated in the same currency with different degrees of liquidity. Though this approach has more restrictive assumptions, it would be advantageous if higher-quality national Divisia indexes could be used.

${ }^{22}$ Following the literature, aggregation is performed over the components of the official aggregates and implicitly assumes that weak separability is satisfied (see also Thornton and Yue, 1992; Fisher, Hudson, and Pradhan, 1993; or Gaab and Mullineux, 1996)

${ }^{23}$ Expected depreciation is proxied by actual depreciation, assuming zero uncertainty and agents with rational expectations. These assumptions are restrictive and do not hold in practice. However, because expected depreciation enters in the numerator and denominator of the user cost, errors may cancel out partially. To capture uncertainty, the user cost could be adjusted by an additional term reflecting the interestrate and exchange-rate risk (see Bamett and Liu, 1995). This aspect, however, is neglected here. holdings that results from exchange-rate fluctuations. A capital gain caused by an appreciation of the exchange rate is treated like the interest yield of a monetary asset. Though national currencies have different user costs, consumers hold all of them because they are imperfect substitutes. If they were perfect substitutes, the representative consumer would hold only the currency with the lowest user cost.

\section{Construction of the Index}

The countries investigated are Germany, France, and the N etherlands, the most likely candidates for a core monetary union. A currency union without Germany and F rance is inconceivable, since these two countries are the driving forces behind European unification. The N etherlands, being the only country for which the narrow exchange rate targets currently apply, has close economic relations with Germany as well as with France. Data are quarterly from 1973:1 to $1994: 4 .{ }^{19}$

The simple-sum European money stock is converted with current exchange rates and expressed in a weighted currency. ${ }^{20}$ As in Fase and Winder (1994) and Monticelli and Papi (1996), aggregation is performed over two different groups of monetary assets: narrow money (M 1) and quasi money (M 3-M1) as defined in the International Financial Statistics. ${ }^{21,22}$ The income variable, gross domestic product (GDP), is also converted into a weighted currency. The European price index, used to deflate the simple-sum and the Divisia aggregates, is obtained through aggregation of national consumer price indexes with GDP weights, based on current exchange rates.

I dentifying the benchmark asset is difficult. Conceptually, the benchmark asset offers no transactions services and can be used only to transfer wealth between periods. Moreover, in order to be comparable to monetary assets, the benchmark asset should be capital-certain, and its yield should not include a risk premium (see Fisher, Hudson, and Pradhan, 1993). The yield on government bonds is taken as the benchmark rate, although even longterm bonds are not completely illiquid. To construct a European benchmark rate, we assume that bonds denominated in different currencies perform the same function - i.e., the transfer of wealth between periods. So the benchmark rate becomes the highest national interest rate, corrected for expected depreciation. ${ }^{23}$

In theory, the benchmark yield is the maximum expected holding-period yield in the economy (Barnett, Fisher, and Serletis, 1992). ${ }^{24}$ Any asset that yields monetary or liquidity services must earn less interest than the benchmark asset. In reality, however, interest rates on time deposits are often higher than long-term rates. This would cause the user costs to become negative if the long-term rate is taken to be the benchmark rate.

To avoid negative user costs, which make no sense, two types of adjustments have been used. In the first, the user cost is augmented by its minimum value. This approach can be interpreted as a "liquidity mark-up," since data on the theoretically correct benchmark yield are difficult to identify. This method is arbitrary, however, as the particular minimum value depends on the sample period. In the second approach, the asset yielding the highest return in the period is taken to be the benchmark asset. Fisher, Hudson, and Pradhan (1993) argue that in principle the benchmark asset should not provide monetary services and, therefore, an asset that is included as money in a previous time period should not be used later as the benchmark. Thus in some periods an asset will have a zero user cost and a resulting zero contribution to the growth rate of the monetary index. Only results for the index obtained with the second method are presented here. ${ }^{25}$ It is generally assumed that $\mathrm{M} 1$ earns no interest. For the interest rate on quasi money, I use the money market rate. ${ }^{26}$

Figures la to 1c show the user cost for narrow money and quasi money for each of the three countries. The user costs for $\mathrm{M} 1$ are very similar for all countries after 1987 because of the convergence of nom- 


\section{Figures $1 \mathrm{a}-1 \mathrm{c}$}

\section{User Cost for Narrow Money and Quasi Money (Percent)}
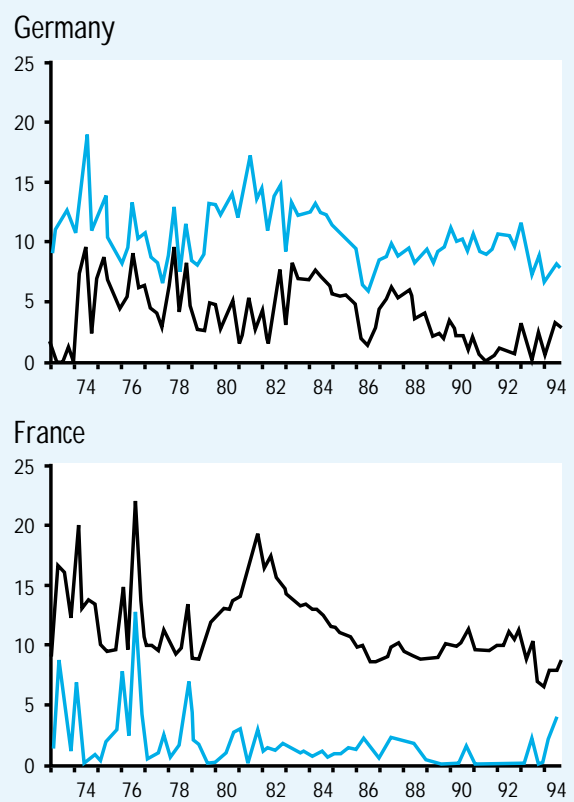

Netherlands

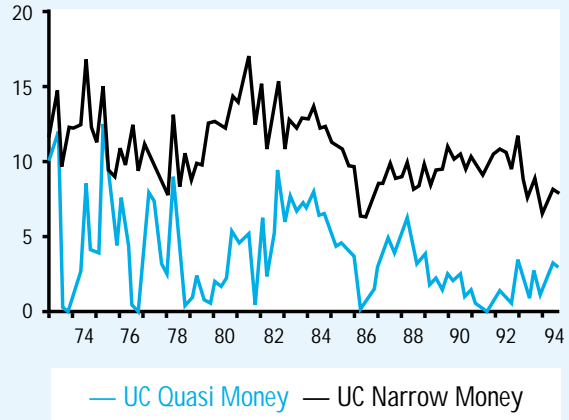

inal interest rates during the "hard" period of the European Monetary System following the Basle-N yborg agreement in 1987. Even the widening of the exchange rate bands in 1993 had almost no effect on the user cost, since neither the French franc nor the Dutch guilder depreciated significantly against the German mark.

The user cost of quasi money is surprisingly low for France because the short-term interest rate in France is relatively high - often higher than the government bond yield. Consequently, the French money market rate is frequently

\section{Figures $2 \mathrm{a}-2 \mathrm{c}$}

\section{Annual Growth Rate of Narrow Money and Quasi Money (Percent)}

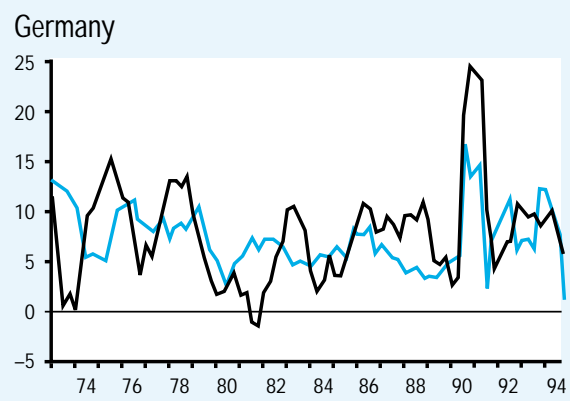

France

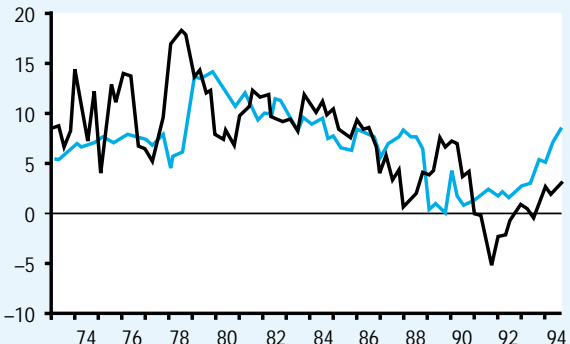

Netherlands

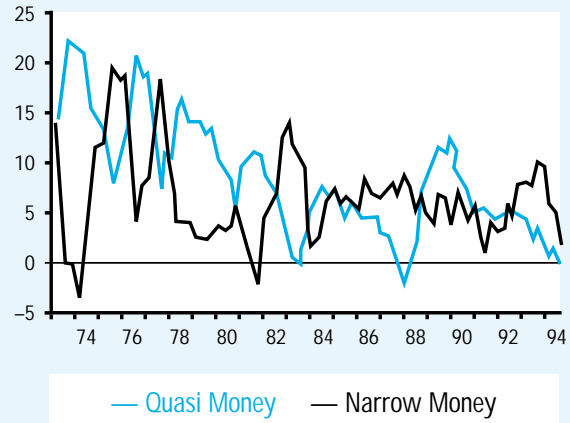

the benchmark rate. After the establishment of the European M onetary System, the user costs for the three countries narrowed considerably, indicating progress in monetary and financial integration.

Figures $2 \mathrm{a}$ to $2 \mathrm{c}$ show the growth of the monetary components in the three countries. The German Unification is denoted by the sharp spike in money growth rates in 1990, with M 1 growing more rapidly than quasi money. Money growth in France declined steadily after the beginning of the ' 80 s. After German Unification, France had to follow a very
${ }^{24}$ To be comparable, interest rates should be holding-period adjusted; liquidity premia are generally higher on longer maturity assets. This can be done by estimating a yield curve adjustment ( see e.g., Anderson, Jones, and Nesmith, 1997b, or Farr and Johnson, 1985). Unfortunately, in the Intemational Financial Statistics no data on the yield curve for government bonds are available. The own rates on monetary assets, however, are comparable as they refer to the same holding period.

${ }^{25}$ Which of these two adjustments for negative user costs is used makes no qualitative difference for the empirical results. To avoid taking logarithms of zero, a very small constant of less than a basis point was further added to the user costs (see Anderson, Jones, and Nesmith, 1997b).

${ }^{26} \mathrm{~A}$ deposit rate would have been preferable but was not available for all countries over the sample period. 


\section{Table 1}

\section{Nominal Growth Rates of Monetary Aggregates}

\begin{tabular}{|c|c|c|c|c|}
\hline & QM3 & M3 & M3-M 1 & M 1 \\
\hline $\begin{array}{l}\text { Sample 73:1-94:4 } \\
\text { Mean } \\
\text { Standard deviation }\end{array}$ & $\begin{array}{l}7.39 \\
2.56\end{array}$ & $\begin{array}{l}7.69 \\
2.30\end{array}$ & $\begin{array}{l}7.66 \\
2.43\end{array}$ & $\begin{array}{l}7.74 \\
3.08\end{array}$ \\
\hline $\begin{array}{l}\text { Sample 73:1-78:4 } \\
\text { Mean } \\
\text { Standard deviation }\end{array}$ & $\begin{array}{l}8.79 \\
2.44\end{array}$ & $\begin{array}{l}9.36 \\
1.26\end{array}$ & $\begin{array}{l}9.01 \\
1.41\end{array}$ & $\begin{array}{c}10.04 \\
3.49\end{array}$ \\
\hline $\begin{array}{l}\text { Sample 79:1-86:4 } \\
\text { Mean } \\
\text { Standard deviation }\end{array}$ & $\begin{array}{l}8.17 \\
2.12\end{array}$ & $\begin{array}{l}8.56 \\
1.97\end{array}$ & $\begin{array}{l}8.81 \\
2.25\end{array}$ & $\begin{array}{l}8.07 \\
2.11\end{array}$ \\
\hline $\begin{array}{l}\text { Sample 87:1-90:2 } \\
\text { Mean } \\
\text { Standard deviation }\end{array}$ & $\begin{array}{l}5.80 \\
0.98\end{array}$ & $\begin{array}{l}5.57 \\
1.34\end{array}$ & $\begin{array}{l}5.27 \\
1.62\end{array}$ & $\begin{array}{l}6.15 \\
1.22\end{array}$ \\
\hline $\begin{array}{l}\text { Sample 90:3-94:4 } \\
\text { Mean } \\
\text { Standard deviation }\end{array}$ & $\begin{array}{l}5.38 \\
2.50\end{array}$ & $\begin{array}{l}5.56 \\
1.57\end{array}$ & $\begin{array}{l}5.67 \\
1.55\end{array}$ & $\begin{array}{l}5.34 \\
2.63\end{array}$ \\
\hline
\end{tabular}

NOTES: "OM3" denotes the Divisia aggregate, "M3" the simple-sum monetary aggregate, "M1" narrow money, and "M3- M1" quasi money for Germany, France, and the Netherlands. Annual growth rates in percent.

restrictive monetary policy to support its exchange rate. This is reflected in the sharp drop in M 1 growth in 1990, and in the relatively slow money growth and quasi money growth thereafter. Money growth slowed over the sample period in the N etherlands, al though no clear effect of German Unification is seen. This is not surprising, since the N etherlands did not experience an exchange-rate crisis.

Substitutability between narrow money and quasi money appears to be high for all these countries, but particularly so for the $N$ etherlands. This is especially true at the beginning of the sample period when the growth rates of narrow money and quasi money moved in opposite directions. The user costs for non-interest-bearing money are highest in France because, on average, France had higher inflation in the first part of the sample leading to exchange-rate depreciation against both of the other currencies.

Figures $3 a$ and $3 b$ compare the annual growth rates of the European Divisia indexes and the traditional simple-sum aggregates. From 1982 on, the growth

\section{Figures 3 a, 3 b}

\section{Annual Growth Rates Divisia and M1}

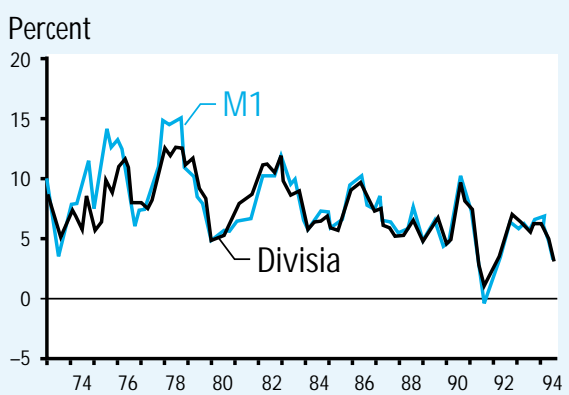

Divisia and M3

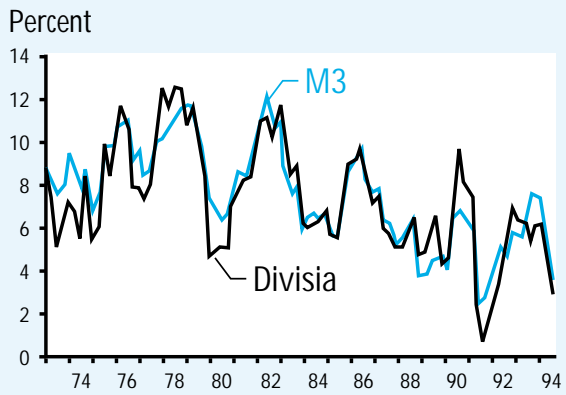

rates of the Divisia index and M 1 were very close. As the money market rate is used as own rate on quasi money, the user cost for quasi money is presumably too low because time and savings deposits in general earn an interest rate below the money market rate. Consequently, the share of quasi money in the index is biased downwards, and the Divisia aggregate behaves much like M 1 .

Table 1 shows descriptive statistics for the whole sample period as well as for different subperiods. Like the national Divisia indexes for 10 European countries computed by Fase and Winder (1994), nominal Divisia money shows a lower average growth rate and a higher standard deviation than simple-sum M 3.27

Differences between the growth rates of the Divisia index and the traditional aggregates are not significant for any sample period. From 1987 onwards, the growth rate of all aggregates fell considerably. Even after German Unification, money growth was lower than in every other subsample, despite the rise in the German
(1993) for Germany, and by Gaiotti (1994) for Italy. 


\section{Unit Root Tests}

\begin{tabular}{lccccc} 
Variable & ADF Level & ADF 1. Diff. & \multicolumn{2}{c}{ Regression } & Condusion \\
\hline QM3R & -2.858 & -3.781 & $\mathrm{~T}$ & $\mathrm{C}$ & unit root \\
M3R & -3.075 & -3.303 & $\mathrm{~T}$ & $\mathrm{C}$ & unit root \\
EXPR & -4.409 & -5.631 & $\mathrm{~T}$ & $\mathrm{C}$ & trend stationary \\
GDPR & -3.306 & -3.318 & $\mathrm{~T}$ & $\mathrm{C}$ & unit root \\
PQ & -1.954 & -5.433 & $\mathrm{C}$ & $\mathrm{N}$ & unit root \\
GBY & -2.257 & -3.619 & $\mathrm{C}$ & $\mathrm{N}$ & unit root
\end{tabular}

NOTES: "QM3R" is real Divisia money, "M3R" real simple-sum money. "EXPR" denotes real expenditure on consumption and monetary services, "GDPR" real gross domestic product, "PQ" the price dual to the Divisia index, and "GBY" the government bond yield. Except for the government bond yield, all variables are in logs. The sample period is 1973:1 to 1994:4. "ADF Level" and "ADF 1. Diff." are the Augmented Dickey-Fuller test statistics for the levels and the first differences of the variables, respectively. The "Regression" column shows the specification of the test, with the first entry referring to the test of the levels, and the second entry the test of the first differences of the variables. " $T$ " indicates the inclusion of a trend and a constant, " $C$ " the inclusion of a constant only, and "N" a test without trend and constant. All tests include four lags. Critical values are - 3.464 for the tests induding a trend and a constant, -2.896 for the tests with a constant only, and -1.946 for the tests without trend and constant (MacKinnon, 1991).

money stock. This rise was compensated by a very slow money growth in France. In general, all monetary aggregates show the same picture and are consistent with the lower inflation and the more stable exchange rates that have prevailed in Europe since the mid-' 80 s.

\section{Money Demand}

Analysts often assess the performance of a Divisia index by estimating a demand function for Divisia money and comparing it to the money demand function for a simple-sum aggregate. ${ }^{28}$ Money demand functions generally include real income and an interest rate as explanatory variables. However, Barnett (1996) argues that these variables are inconsistent with demand theory. The Divisia index is derived from a utility maximization framework; hence, the demand for Divisia money should be model ed according to demand theory as the first stage of the budget al location, in which the agent allocates his expenditures among consumption goods and monetary services. However, national income does not correspond to the representative agent's income as it appears in the budget constraint. For example, GDP contains components such as investment that do not appear in the budget constraint.
Furthermore, expenditures on monetary services are not included in GDP but would be included in the representative household's budget constraint. Similar considerations apply to the opportunity cost variable frequently used in money demand estimations. Modeling the demand for Divisia money in the conventional way is justifiable from a policymaker's perspective. A measure of money is useful to the policymaker only insofar as it conveys information about the behavior of objective variables, such as prices and output (see Pill and Pradhan, 1994).

Two different money demand equations for Divisia money are estimated here: The first one uses expenditures on consumption and monetary services as the income variable ${ }^{29}$ and the Divisia price dual ${ }^{30}$ as opportunity cost. The second uses GDP and an interest rate as regressors. These regressions are compared to a conventional simple-sum money demand function.

\section{EMPIRICAL RESULTS}

Before the model is specified, the time series are tested for their order of integration. Table 2 presents the results of the unit root tests. Most variables are integrated of order one; only real expenditures seem to be trend-stationary in levels.
${ }^{28}$ See, e.g., Gaab and Mullineux (1996), and Bamett (1982).

${ }^{29}$ Data on private consumption expenditures are from the OECD National Accounts. Data were converted to 1990 prices for France (1980 prices) and Germany (1991 prices). For the Netherlands, consumption data from 1973:1 to 1976:4 were extrapolated with GDP data. As for Germany, pre-unification data are seasonally adjusted and post-unification data are not; these were adjusted by a regression on three seasonal dummies and a constant.

${ }^{30}$ The price dual is computed by dividing total expenditure on monetary assets by the Divisia quantity index. As the Divisia index is computed over real monetary assets, the corresponding price dual is nominal (see Anderson, Jones, and Nesmith, 1997b). 
Table 3

\section{Estimation Results for the Long-Run Relation}

\begin{tabular}{lrrr} 
Variable & QM3R & QM3R & M3R \\
\cline { 2 - 4 } Constant & -22.002 & -23.519 & -8.722 \\
EXPR/ GDPR & 0.875 & 0.869 & 0.971 \\
PQ/GBY & -0.224 & -0.015 & -0.013 \\
& & & \\
Adj. R & 0.975 & 0.977 & 0.988 \\
Durbin-Watson & 0.514 & 0.468 & 0.326 \\
Dickey-Fuller & -3.935 & -4.203 & -3.228
\end{tabular}

NOTES: All regressions indude a dummy for German Unification, which takes the value of 1 from 1990:3 on, and seasonal dummies. The first column shows the regression of the real Divisia aggregate on real expenditure and the price dual. The second column regresses the real Divisia aggregate on real GDP and the government bond yield. The third column gives the results for real M3, real GDP, and the government bond yield. The last line shows the Dickey-Fuller test statistic for stationarity of the residuals. The critical value for the 5 percent level is - 3.840 (McKinnon, 1991). See also notes to Table 2.

${ }^{31}$ In fact, parameter estimates are superconsistent: they converge asymptotically against the true parameter values at an even faster rate than in usual OLS regressions. Small sample bias, however, can be severe (see Banerjee et al., 1993).

32 The Engle-Granger method is less efficient than the Johansen approach, since the long-run relation is estimated without the information in the dynamic adjustment. Moreover, with more than two variables, testing for the existence of multiple cointegrating vectors is impossible. On the other hand, the Johansen method is often very sensitive to the lag choice.

${ }^{33}$ T-values are not shown, since their distribution is nonstandard.
Money demand is estimated with the Engle-Granger method, which uses ordinary least squares to estimate the long-run relation. Though non-stationary variables are involved in the regression, parameter estimates remain consistent. ${ }^{31}$ If cointegration exists - that is, if the variables move together in the long run - the residuals must be stationary. Nevertheless, they may exhibit autocorrelation or non-normality because the dynamic adjustment is not modeled in the first step. ${ }^{32}$

Results for the long-run relations are shown in Table 3. Three different equations are estimated. The first column shows the results for the Divisia money demand regression, including the real Divisia quantity index, expenditures on consumption and monetary services, and the price dual. The second column regresses the Divisia index on GDP and the government bond yield. The third column gives the results for a conventional money demand equation for M3. All regressions include four seasonal dummies and a dummy for German Unification that takes the value of one from the third quarter of 1990 onwards and zero elsewhere.

The income elasticity is close to unity in all three regressions, though the point estimate for the Divisia equations is slightly lower than that of simple-sum M 3. ${ }^{33}$ The price dual elasticity is much higher for the
Divisia aggregate than the interest rate elasticity of simple-sum M 3. N evertheless, if the Divisia aggregate is regressed on GDP and the government bond yield, the results are almost identical to those obtained with M3. Stationarity of the residuals is tested with a Dickey-Fuller test. Residuals are stationary at the 5 percent level for both of the Divisia regressions but not for M3.

$\mathrm{N}$ ext, the dynamic adjustment to the long-run relationship is modeled. Dynamic models are specified according to the general-to-specific approach, starting with four lags of each variable. Insignificant terms have been eliminated. Table 4 shows the final specifications, including the errorcorrection term, a dummy for German monetary union, and four seasonal dummies.

Each of the dynamic models is satisfactory. For M 3, lagged changes of real GDP have no significant effect. In all equations, the error-correction term is highly significant. For the Divisia aggregate, about 20 percent of the deviation from equilibrium is corrected each quarter, whereas the error-correction term for M3 is slightly lower.

\section{CON CLUSION}

The Divisia index has microeconomic foundations and empirically performs better than the simple-sum M3. While the aggregation approach regards money as a durable consumption good yielding a flow of services, simple-sum aggregation treats money as a component of wealth in a simple accounting procedure. In this paper, a consistent framework for the aggregation of monetary assets in different currencies has been developed. With completely fixed exchange rates, the European Divisia index equals the conventional Divisia index, since depreciation vanishes. If a common currency is introduced, monetary assets of the same degree of liquidity become indistinguishable for the consumer and can be aggregated across countries by simplesum aggregation.

The advantage of the Divisia index is likely to be important during the transition to monetary union, because this index can 
take account of increased exchange-rate stability. Moreover, it can cope better with financial innovation. The move to a currency union will liberalize financial markets and increase competition in the banking sector, and will presumably lead to new financial products in those countries where markets are still regulated. As payments systems still differ among the European countries, the Divisia index may give a more appropriate indication of liquidity in Europe until a completely integrated financial market has developed (see Spencer, 1995). Even after the financial markets have been completely integrated, the Divisia index would continue to be more valid than simple-sum measures, because substitution effects between assets with different degrees of liquidity will remain.

Though the Divisia index performs slightly better, the empirical differences between the Divisia index and simple-sum M3 with regard to money demand are small. This lack of striking findings is probably a result of the degree of disaggregation, since the breakup into narrow money and quasi money is a very crude one. Nevertheless, the Divisia index of European monetary services may provide additional insight into money demand during the period of transition to monetary union. With more disaggregated data on monetary assets and the corresponding interest rates, the performance of the Divisia index relative to simple-sum indexes would likely improve. Therefore, the European Monetary Institute should monitor Divisia aggregates in addition to $\mathrm{M} 3$ during the transition to a monetary union.

\section{REFERENCES}

Anderson, Richard G., Barry E. Jones, and Travis D. Nesmith. "Monetary Aggregation Theory and Statistical Index Numbers," this Review (January/ February 1997a), pp. 31-51.

Anderson, Richard G., Barry E. Jones, and Travis D. Nesmith. "Building New Monetary Services Indices: Concepts, Data and Methods," this Review (Januaryl February 1997b), pp. 53-82.

Artis, Michael J., Robin C. Bladen-Hovell, and Wenda Zhang. "A European Money Demand Function," Policy Issues in the Operation of Currency Unions, Paul R. Masson, and Mark P. Taylor, eds., Cambridge University Press, 1993, pp. 240-65.

\section{Table 4}

\section{Dynamic Equations}

\begin{tabular}{|c|c|c|c|}
\hline Variable & $\Delta Q M 3 R$ & $\Delta Q M 3 R$ & $\Delta M 3 R$ \\
\hline $\begin{array}{l}\text { Constant } \\
\Delta \mathrm{M} 3 \mathrm{R}(-1)\end{array}$ & $\begin{array}{l}-0.170 \\
(-4.994)\end{array}$ & $\begin{array}{c}-0.019 \\
(-4.369)\end{array}$ & $\begin{array}{c}-0.007 \\
(-2.209) \\
0.194 \\
(2.179)\end{array}$ \\
\hline $\begin{array}{l}\Delta Q M 3 R(-4) / \\
\Delta M 3 R(-4) \\
\Delta \text { EXPR }\end{array}$ & $\begin{array}{c}0.410 \\
(5.060) \\
0.314 \\
(3.508)\end{array}$ & $\begin{array}{c}0.391 \\
(4.582)\end{array}$ & $\begin{array}{c}0.189 \\
(2.140)\end{array}$ \\
\hline$\Delta \operatorname{GDPR}(-1)$ & & $\begin{array}{c}0.305 \\
(1.772)\end{array}$ & \\
\hline$\Delta \mathrm{PQ} / \Delta \mathrm{GBY}$ & $\begin{array}{l}-0.077 \\
(-4.023)\end{array}$ & $\begin{array}{c}-0.009 \\
(-2.988)\end{array}$ & $\begin{array}{c}-0.006 \\
(-4.023)\end{array}$ \\
\hline RES(- 1) & $\begin{array}{l}-0.206 \\
(-4.011)\end{array}$ & $\begin{array}{l}-0.221 \\
(-4.070)\end{array}$ & $\begin{array}{c}-0.144 \\
(-4.011)\end{array}$ \\
\hline $\begin{array}{l}\text { Adj. } R^{2} \\
\text { SEE } \\
\text { Durbin-Watson }\end{array}$ & $\begin{array}{l}0.824 \\
0.013 \\
1.902\end{array}$ & $\begin{array}{l}0.832 \\
0.012 \\
1.931\end{array}$ & $\begin{array}{l}0.773 \\
0.008 \\
2.003\end{array}$ \\
\hline
\end{tabular}

Banerjee, Anindya, Juan J. Dolado, John W. Galbraith, and David F. Hendry. Co-Integration, Error Correction, and the Econometric Analysis of Non-Stationary Data, Oxford University Press, 1993.

Bamett, William A. "The User Cost of Money," Economics Letters (vol. 1, 1978), pp. 145-49.

_. . . . Consumer Demand and Labor Supply: Goods, Monetary

Assets, and Time, Amsterdam: North-Holland, 1981.

. "The Optimal Level of Monetary Aggregation," Journal of Money, Credit, and Banking (November 1982), pp. 687-711.

. "The Microeconomic Theory of Aggregation," New Approaches to Monetary Economics: Proceedings of the Second International Symposium in Economic Theory and Econometrics, William A. Barnett and Kenneth J. Singleton, eds., Cambridge University Press, 1987, pp. 115-68.

"Which Road Leads to Stable Money Demand?," forthcoming in The Economic Journal.

, Douglas Fisher, and Apostolos Serletis. "Consumer Theory and the Demand for Money," Jourmal of Economic Literature, (December 1992), pp. 2086-119. , and Yi Liu. "The CAPM-Extended Divisia Monetary Aggregate with Exact Tracking Under Risk," Working Paper No. 194, Washington University, St. Louis, 1995.

Diewert, W. Erwin. "Exact and Superlative Index Numbers," Journal of Econometrics, (May 1976), pp. 115-45. 
Divisia, François. "Lindice Monétaire et la Théorie de la Monnaie," Revue d'Economie Politique (1925), pp. 980-1008.

Donovan, Donald J. " Modeling the Demand for Liquid Assets: An Application to Canada," International Monetary Fund Staff Papers (December 1978), pp. 676-704.

Ewis, Nabil A., and Douglas Fisher. "The Translog Utility Function and the Demand for Money in the United States," Journal of Money, Credit, and Banking (February 1984), pp. 35-52.

Farr, Helen T., and Deborah Johnson. "Revisions in the Monetary Services (Divisia) Indexes of the Monetary Aggregates," Staff Study 147, Board of Governors of the Federal Reserve System, December 1985.

Fase, Martin M. G. "Divisia Aggregates and the Demand for Money in Core EMU," De Nederlandsche Bank Staff Reports No. 5, 1996. , and C. C. A. Winder. "Money Demand within EMU: An Analysis with the Divisia Measure," De Nederlandsche Bank Quarterly Bulletin (September 1994), pp. 25-55.

Fisher, Paul G., Suzanne Hudson, and Mahmood Pradhan. "Divisia Measures of Money," Quarterly Bulletin, Bank of England, (May 1993), pp. 240-52.

Gaab, Werner, and Andy Mullineux. "Financial Innovation, Monetary Aggregates and Monetary Policy in the UK and Germany," Finanzmärkte, Finanzinnovationen und Geldpolitik, Schriften des Vereins für Socialpolitik, Bd. 242, D. Duwendag, ed., Berlin: Duncker und Humblot, 1996, pp. 73-110.

Gaiotti, Eugenio. "Measuring Money with a Divisia Index: An Application to Italy," Temi di Discussione del Senvizio Studi 223, Banca d'Italia, 1994.

Green, H. A. John. Aggregation in Economic Analysis: An Introductory Survey, Princeton University Press, 1964.

Issing, Otmar, Karl-Heinz Todter, Heinz Hermann, and Hans-Eggert Reimers. "Zinsgewichtete Geldmengenaggregate und M3 - ein Vergleich," Kredit und Kapital (Vol. 26, Issue 1, 1993), pp. 1-21.

Kremers, Jeroen J. M., and Timothy D. Lane. "Economic and Monetary Integration and the Aggregate Demand for Money in the EMS," International Monetary Fund Staff Papers (December 1990), pp. $777-805$.

MacKinnon, James G. "Critical Values for Cointegration Tests," Long-Run Economic Relationships, Robert F. Engle and Clive W. J. Granger, eds., Oxford University Press, 1991, pp. 267-76.

Marquez, Jaime. "Money Demand in Open Economies: A Divisia Application to the U.S. Case," New Approaches to Monetary Economics, Proceedings of the Second International Symposium in Economic Theory and Econometrics, William A. Bamett, and Kenneth J. Singleton, eds., Cambridge University Press, 1987, pp. 183-99.

OECD. Purchasing Power Parities and Real Expenditures - GK Results, Vol. 2, Paris: Organisation for Economic Co-operation and Development, 1993.

Osbome, Dale K. "Defining Money," The New Palgrave Dictionary of Money and Finance, Peter Newman, Murray Milgate, and John Eatwell, eds., Macmillan, 1992, pp. 602-06.
Phlips, Louis. Applied Consumption Analysis, Amsterdam: North-Holland, 1974.

Pill, Huw, and Mahmood Pradhan. "Monetary Aggregation: A Reconciliation of Theory and Central Bank Practice," Intemational Monetary Fund Working Paper 118 (October 1994).

Rotemberg, Julio J., John C. Driscoll, and James M. Poterba. "Money, Output, and Prices: Evidence from a New Monetary Aggregate," Journal of Business and Economic Statistics (January 1995), pp. 67-83.

Spencer, Peter. "Should the ECB Adopt a Divisia Monetary Aggregate?," paper presented at the CEPR/ Irving Fisher Society Conference: What Monetary Policy for the European Central Bank?, 1995.

Swofford, James L, and Gerald A. Whitney. "Flexible Functional Forms and The Utility Approach to the Demand for Money: A Nonparametric Analysis," Journal of Money, Credit, and Banking (August 1986), pp. 383-89.

, and _. . . "Nonparametric Tests of Utility Maximization and Weak Separability for Consumption, Leisure and Money," Review of Economics and Statistics (August 1987), pp. $458-64$.

, and _._. . "A Comparison of Nonparametric Tests of Weak Separability for Annual and Quarterly Data on Consumption, Leisure, and Money," Journal of Business and Economic Statistics (April 1988), pp. 241.46. , and _. _. . "A Revealed Preference Test for Weakly Separable Utility Maximization with Incomplete Adjustment," Journal of Econometrics (Januaryl February 1994), pp. 235-49.

Thornton, Daniel L., and Piyu Yue. "An Extended Series of Divisia Monetary Aggregates," "this Review (Novemberl December 1992), pp. 35-52.

Wesche, Katrin. "Aggregating Money Demand in Europe with a Divisia Index," Discussion Paper No. B-393, SFB 303, Universität Bonn, 1996. 